\title{
Phosphofurin Acidic Cluster Sorting Protein 1
}

National Cancer Institute

\section{Source}

National Cancer Institute. Phosphofurin Acidic Cluster Sorting Protein 1. NCI Thesaurus. Code C114566.

Phosphofurin acidic cluster sorting protein 1 (963 aa, $105 \mathrm{kDa}$ ) is encoded by the human PACS1 gene. This protein is involved in mediating the localization of proteins to the Golgi. 